\begin{tabular}{c} 
Tersedia online di: http://ejournal-balitbang.kkp.go.id/index.php/bawal \\
e-mail:bawal.puslitbangkan@ gmail.com \\
BAWAL wIDYA RISET PERIKANAN TANGKAP \\
Volume 8 Nomor 1 April 2016 \\
p-ISSN: 1907-8226 \\
e-ISSN: 2502-6410 \\
BAWALALE \\
Nomor Akreditasi: 620/AU2/P2MI-LIPI/03/2015 \\
\hline \hline
\end{tabular}

\title{
KESEHATAN TERUMBU KARANG DAN STRUKTUR KOMUNITAS IKAN DI PERAIRAN PANTAI PANGANDARAN, JAWA BARAT
}

\section{CURRENT STATE OF REEF HEALTH AND RESOURCES OF REEF FISH IN PANGANDARAN BEACH WATERS, WEST JAVA}

\author{
Sri Turni Hartati ${ }^{* 1}$ dan Arip Rahman ${ }^{2}$ \\ ${ }^{1}$ Pusat Penilitian dan Pengembangan Perikanan, Jalan Pasir Putih II, Ancol Timur Jakarta Utara-14430, Indonesia \\ ${ }^{2}$ Balai penelitian Pemulihan dan Konservasi Sumber Daya Ikan, Jalan Jatiluhur PO BOX 01 Purwakarta, Jawa Barat-41152, \\ Indonesia \\ Teregistrasi I tanggal: 04 Januari 2016; Diterima setelah perbaikan tanggal: 11 April 2016; \\ Disetujui terbit tanggal: 13 April 2016
}

\begin{abstract}
ABSTRAK
Keanekaragaman jenis ikan karang merupakan suatu indikator penting yang dapat menggambarkan perubahan lingkungan perairan karang. Perubahan habitat karang adalah resiko yang mungkin dihadapi sebagai akibat pembangunan. Penelitian dilakukan di perairan pantai Pangandaran dengan tujuan mengkaji kesehatan terumbu karang dan indeks ekologis komunitas ikan karang. Metode yang digunakan dalam penelitian ini adalah line intercept transect untuk menentukan persen tutupan karang dan metode sensus visual untuk menentukan keanekaragaman ikan karang pada area seluas $250 \mathrm{~m}^{2}$. Hasil penelitian menunjukkan kesehatan terumbu karang pada kondisi buruk, tutupan karang hidup 11,4 -20,74\%. Teridentifikasi 66 jenis ikan karang dengan kriteria kepadatan sangat jarang $(0,59-0,91)$ ind $/ \mathrm{m}^{2}$. Indeks kekayaan ikan karang pada kategori baik $(4,60-8,68)$, keanekaragaman jenis ikan karang termasuk dalam kategori sedang $(2,57-3,36)$. Tidak terjadi dominasi jenis ikan karang tertentu $(0,05-0,120)$ dan kemerataan populasi di lokasi penelitian termasuk tinggi $(0,81-0,87)$.
\end{abstract}

Kata Kunci: Kesehatan terumbu karang; ikan karang; indeks keanekaragaman; Pangandaran

\begin{abstract}
Reef fish diversity is a major indicator to expose a current environmental state of coral reefs. Economic developments probably lead to habitat alteration risks. The research was conducted in Pangandaran Beach Waters, Batu Karas, Pananjung Barat, Pananjung Timur. The research objective was, to assess the reef health, and to fine out several diversity indices of reef fish communities. Methods used for those are a line intercept transect and census visual technique within area of $250 \mathrm{~m}^{2}$. The results showed that all of the area had a poor reef health category (11,4-20,74\%), reef fish densities were grouped in very rare areas, especially $<1-5 \mathrm{ind} / \mathrm{m}^{2}$. Richnes indices had a good category (4,60-8,68), shannon diversity indices of reef fish felt in the fair category (2,57$3,36)$, dominance indices of reeffish felt in the low category $(0,05-0,120)$ and evenness indices were felt in a high category $(0,81-0,87)$.
\end{abstract}

Keywords: Reef health; reef fish; diversity indices; Pangandaran 


\section{PENDAHULUAN}

Terumbu karang merupakan salah satu sumberdaya alam yang sangat penting, sebagai penghasil bahan makanan dan sumber penghasilan bagi masyarakat disekitarnya. Namun keberadaan terumbu karang sangat rentan dari ancaman kerusakan yang disebabkan oleh aktifitas manusia. Kerusakan terumbu karang di Indonesia menunjukkan kenaikan yang signifikan, dalam kurun waktu 4 tahun (2004-2008) 34\% berkondisi sangat rusak, dan hanya $4 \%$ yang dalam kondisi sangat baik, dan dikhawatirkan laju degradasi semakin cepat apabila tidak diambil langkah-langkah yang progresif (Anonim, 2013). Proses pemulihan kembali kondisi habitat terumbu karang yang mengalami kerusakan memerlukan waktu yang lama dan akan mempengaruhi komunitas ikan karang disekitarnya. Salah satu indikator kerusakan lingkungan terumbu karang tersebut dicirikan oleh semakin menurunnya keanekaragaman jenis-jenis ikan (Badrudin et al., 2003; Radiarta \& Ermor, 2003).

Ikan karang merupakan ikan yang seluruh siklus hidupnya berada di daerah terumbu karang (Sale, 1991). Kondisi tutupan karang yang berbeda akan mempengaruhi kelimpahan ikan karang, terutama yang memiliki keterkaitan kuat dengan karang hidup (Suharsono, 1996). Jumlah spesies ikan karang yang banyak ditemukan pada terumbu karang merupakan gambaran dari banyaknya microhabitat pada lingkungan tersebut (Allen, 1997). Terdapat tiga bentuk umum interaksi antara ikan karang dengan terumbu karang, yaitu: sebagai tempat berlindung dari pemangsa; sebagai tempat mencari makanan yang meliputi hubungan antara ikan karang dan biota yang hidup pada karang terutama alga; dan interaksi tak langsung akibat struktur karang, kondisi hidrologi dan sedimen (Choat \& Bellwood, 1991).

Pesisir Kabupaten Pangandaran merupakan daerah yang masih dipengaruhi oleh dinamika Samudra Hindia. Terletak pada lahan dengan keadaan morfologi datar bergelombang sampai pegunungan, dengan kemiringan lereng berkisar antara 0-40\%. Ekosistem yang ada di wilayah pesisir pantai pangandaran diantaranya terdapat mangrove dengan sebaran luas \pm 170 hektar, ekosistem Lamun dan ekosistem Terumbu karang. Selain potensi perikanannya, pesisir Kabupaten Pangandaran merupakan daerah tujuan wisata baik wisatawan lokal maupun wisatawan asing. Dampak negatif dari adanya kegiatan wisata antara lain pencemaran dari limbah domestik, kerusakan terumbu karang yang diakibatkan oleh kegiatan wisata air, dan penangkapan ikan yang merusak.

Tujuan dari penelitian adalah untuk mengkaji indeks ekologis komunitas ikan karang yang meliputi kekayaan jenis, keanekaragaman jenis, kemerataan populasi, dominasi dan kepadatan ikan, serta persentase kelompok ikan karang berdasarkan pada jumlah individu dan jenisnya.

\section{BAHANDANMETODE}

Penelitian dilakukan pada Bulan Mei 2015 di tiga lokasi di Pantai Pangandaran (Gambar 1).

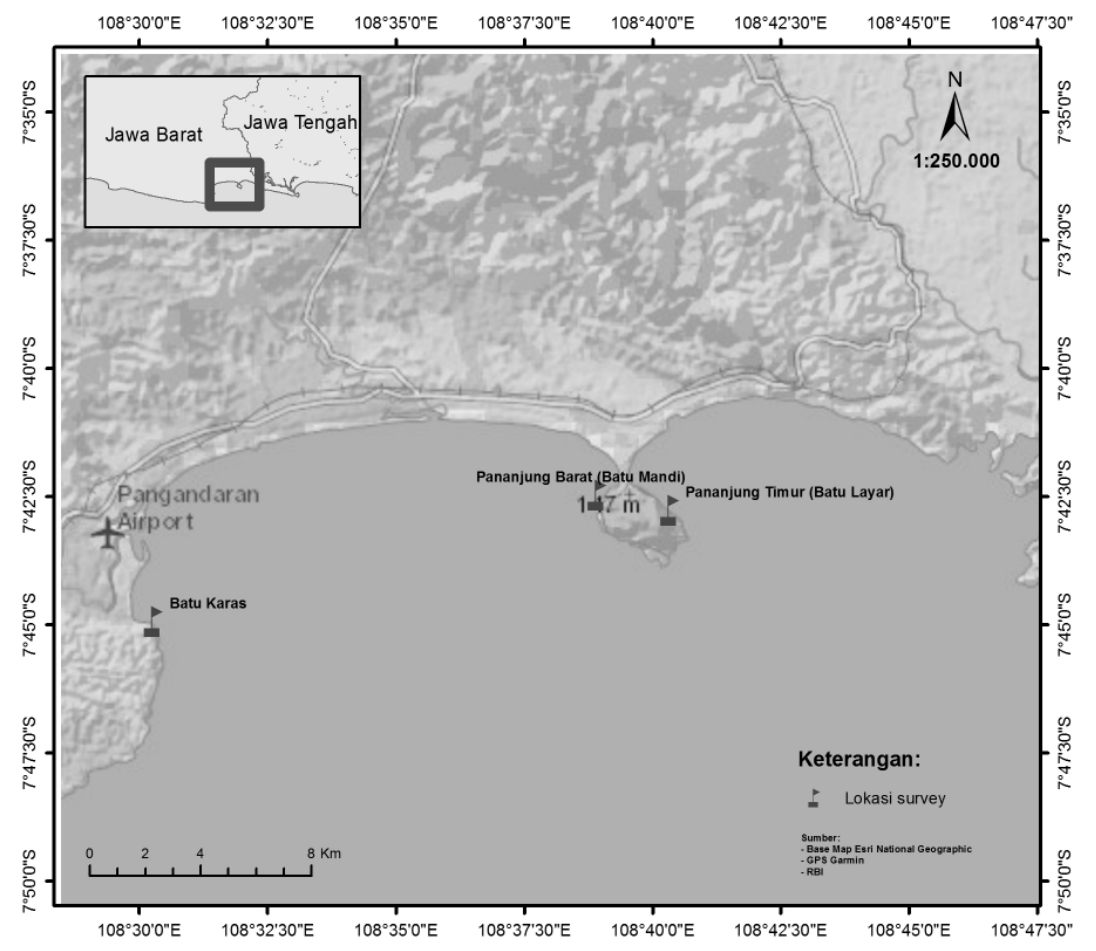

Gambar 1. Peta lokasi penelitian.

Picture 1. Map of research location. 
Metode yang digunakan dalam penelitian ini adalah line intercept transect untuk menentukan persen tutupan karang dan metode sensus visual untuk menentukan keanekaragaman ikan karang (English et al., 1994). Pengamatan ikan karang dilakukan sepanjang garis transek $50 \mathrm{~m}$ dengan jarak pandang ke kiri dan ke kanan 2,5 m, sehingga diperoleh luas area sensus $(50 \times 5) \mathrm{m}^{2}$. Pencatatan dilakukan dengan menggunakan peralatan tulis yang khusus kedap air. Jenis ikan yang ditemukan diidentifikasi dengan menggunakan buku acuan bergambar (Kuiter \& Tonozuka, 2001, Lieske \& Myers, 1997). Analisis untuk

Tabel 1. Indeks biologi dan kriterianya

Table 1. Index Biology and its criteria struktur komunitas ikan menggunakan indeks biologi (Tabel 1). Pengamatan terumbu karang yang mendukung organisme dan habitat, untuk mengidentifikasi persentase tutupan karang batu dan kategori bentuk kehidupan bentik (bentic lifeform). Kategori ini menyediakan deskripsi morfologi komunitas karang.

Untuk mengetahui hubungan antara kehadiran ikan dan kondisi tutupan terumbu karang disekitarnya digunakan analisis korelasi dari data analysis program MS Excel.

\begin{tabular}{|c|c|c|c|}
\hline $\begin{array}{l}\text { Indeks } \\
\text { Index }\end{array}$ & $\begin{array}{c}\text { Rumus Perhitungan } \\
\text { Formula } \\
\end{array}$ & $\begin{array}{l}\text { Kriteria } \\
\text { Criteria } \\
\end{array}$ & $\begin{array}{c}\text { Sumber Acuan } \\
\text { Reference }\end{array}$ \\
\hline Indeks Simpson (D) & $\mathrm{D}=\Sigma\{(\operatorname{ni}(\mathrm{ni}-1) /(\mathrm{N}(\mathrm{N}-1)\}$ & $\begin{array}{l}\mathrm{D} \leq 0.5 \text { (Tidak ada spesies yang } \\
\text { mendominasi) } \\
\mathrm{D} \geq 0.5 \text { (Terdapat spesies yang } \\
\text { mendominasi) }\end{array}$ & (Odum, 1971) \\
\hline Indeks Shanon Weaver $(\mathrm{H})$ & $\mathrm{H}=-\Sigma\{(\mathrm{ni} / \mathrm{N}) * \ln (\mathrm{ni} / \mathrm{N})\}$ & $\begin{array}{l}\mathrm{H}<2.30 \text { (Rendah) } \\
2.31<\mathrm{H}<3.45 \text { (Sedang) } \\
3.46<\mathrm{H}<5.57 \text { (Tinggi) } \\
5.76<\mathrm{H}<6.9 \text { (Sangat Tinggi) }\end{array}$ & (Mason, 1981) \\
\hline Indeks Margalef (R) & $\mathrm{R}=(\mathrm{S}-1) / \ln (\mathrm{N})$ & $\begin{array}{l}\mathrm{R}>4,0 \text { (Baik) } \\
2.5<\mathrm{R}<4 \text { (Sedang) } \\
\mathrm{R}<2.5 \text { (Buruk) }\end{array}$ & $\begin{array}{l}\text { Modifikasi } \\
\text { Jorgensen, et al. } \\
(2005)\end{array}$ \\
\hline Indeks Pielou (E) & $\mathrm{E}=\{\mathrm{H} / \ln (\mathrm{S})\}$ & $\begin{array}{l}\mathrm{E} \leq 0.4 \text { (Rendah) } \\
0.4<\mathrm{E}<0.6 \text { (Sedang) } \\
\mathrm{E} \geq 0.6 \text { (Tinggi) }\end{array}$ & (Odum, 1971) \\
\hline
\end{tabular}

\section{HASIL DAN BAHASAN \\ Hasil}

\section{Status Ekosistem Terumbu Karang}

Ekosistem terumbu karang di Pangandaran, Jawa Barat mengalami kerusakan yang cukup berat setelah terjadinya bencana alam tsunami pada tahun 2006. Kondisi ini diperparah oleh aktivitas nelayan yang masih menggunakan bahan peledak, racun potassium sianida, membongkar dan menginjak nginjak karang pada saat menangkap ikan. Terumbu karang di Pantai pangandaran tersebar di kawasan cagar alam laut Penanjung, yaitu di pantai timur dan pantai barat, membentang sepanjang 1,5 km dengan lebar 20 - $50 \mathrm{~m}$ dan pada kedalaman bervariasi anatara $1-10 \mathrm{~m}$. Tipikal terumbu karang pada umumnya adalah terumbu karang tepi (fringing reef) dengan kontur landai (slope). Bentuk terumbu karang sebagian besar adalah karang-karang massif yang semestinya bisa bertahan dengan baik dari gelombang Samudera Hindia yang keras (Nugraha, 2012). Kerusakan terumbu karang yang terjadi menunjukkan tidak efektifnya cagar alam laut Panjung Pangandaran yang ditetapkan berdasarkan SK MenHut No. 225 /Kpts-II/1990, pada tanggal 8 Mei 1990.
Hasil sensus visual tutupan terumbu karang menunjukkan bahwa pada ke tiga stasiun pengamatan (Batu Karas, Penanjung Barat, Penanjung Timur) tutupan karang keras (hard coral) yang hidup relative rendah, yaitu hanya pada kisaran 11,4 -20,74\% (Tabel 2). Menurut Chou (1998), kerusakan terumbu karang dapat dinilai dengan menggunakan persen tutupan karang keras (hard corals) yang hidup, yaitu sangat baik (excellent) $>75 \%$; baik (good) $<75 \%->50 \%$; sedang (fair) $<50->25 \%$; dan buruk (poor) $<25 \%$. Mengacu pada kriteria tersebut, ekosistem terumbu karang di perairan Pangandaran menunjukkan pada kondisi buruk. (Tabel 2). Tutupan terumbu karang di pantai pangandaran lebih didominasi oleh algae di stasiun pengamatan Batu Karas dan Penanjung Barat $(72,74 \%$ dan $81,93 \%)$ dan abiotic di stasiun Penanjung Timur $(42,94 \%)$

Karang keras yang dijumpai di perairan Batu Karas adalah Non Acropora, yang didominasi oleh Coral Foliose (13\%), Coral Encrusting (6,67\%), dan Coral Massive hanya $0,17 \%$. Karang keras di perairan Penanjung Barat dan Penanjung Timur adalah Acropora dan Non Acropora. Acropora Branching di Penanjung Barat sebesar 2,83\% dan di Penanjung Timur sebesar 13\%, 
sedangkan Non Acropora di Penanjung Barat terdiri dari Coral Mushroom 5,33\%, Coral Encrusting 2,17\%, Coral Massive 1,00\%, dan Non Acropora di Penanjung Timur terdiri dari Coral Mushroom 4,50\%, Coral Foliose 0,07\%, Coral Encrusting 2,17\% dan Coral Massive 1\%.

Kehadiran algae yang relative tinggi di stasiun pengamatan Batu Karas dan Penanjung Barat, meliputi Macro Algae, Turf Algae, Coraline Algae, dan Algal Assemblage, yang didominasi oleh Turf Algae, yaitu pada kisaran 46,93 - 58,47\%. Pada stasiun pengamatan Penanjung Timur persentase abiotic tinggi, yaitu sand $34,44 \%$ dan rubble $8,5 \%$. Biota lain yang dijumpai pada ke tiga stasiun pengamatan adalah Sponge dengan kisaran 4 $-6,67 \%$.

\section{Struktur Komunitas Ikan}

Hasil pengamatan menunjukkan bahwa pada keseluruhan stasiun penelitian terumbu karang teridentifikasi 66 jenis/spesies ikan karang dari 39 marga/ genus dan 17 suku/famili, dengan variasi antar lokasi 24 49 jenis. Jumlah individu pada setiap stasiun pengamatan yang menunjukkan kelimpahan berkisar antara antara 165225 individu. Dengan demikian dengan luasan daerah sapuan $250 \mathrm{~m}^{2}$, kapadatan ikan berkisar 0,59-0,91 ind $/ \mathrm{m}^{2}$, tertinggi di perairan Batu Karas dan yang terendah di Penanjung Timur (Lampiran 1).

Jenis ikan yang paling banyak ditemukan adalah dari famili Labridae $(18.46 \%)$ yang kemudian disusul oleh Chaetodontidae (13.85\%), Pomacentridae (10.77\%) dan famili lainnya dengan persentase kurang dari $10 \%$ disajikan pada Gambar 3.

Pengelompokan jenis ikan karang dibagi menjadi beberapa kategori, yaitu kelompok ikan major, ikan target dan ikan indikator (English et al., 1997). Komposisi kelompok jenis ikan karang berdasarkan lokasi penelitian disajikan pada Gambar 4.

Tabel 2. Persentase tutupan terumbu karang di Perairan Pangandaran

Table 2. Coral reef percent cover in Pangandaran Waters

\begin{tabular}{lccccc}
\hline \multirow{2}{*}{$\begin{array}{c}\text { Lokasi Penelitian } \\
\text { Research location }\end{array}$} & \multicolumn{5}{c}{$\begin{array}{c}\text { Tutupan terumbu karang (\%) } \\
\text { Coral reef percent cover }\end{array}$} \\
\cline { 2 - 6 } & Hard Coral & Dead Coral & Algae & Biota Lain & Abiotic \\
\hline Batu Karas & 19,84 & - & 72,74 & 7,43 & - \\
Penanjung Barat & 11,4 & - & 81,93 & 6,67 & - \\
Penanjung Timur & 20,74 & - & 29,77 & 6,67 & 42,4 \\
\hline
\end{tabular}

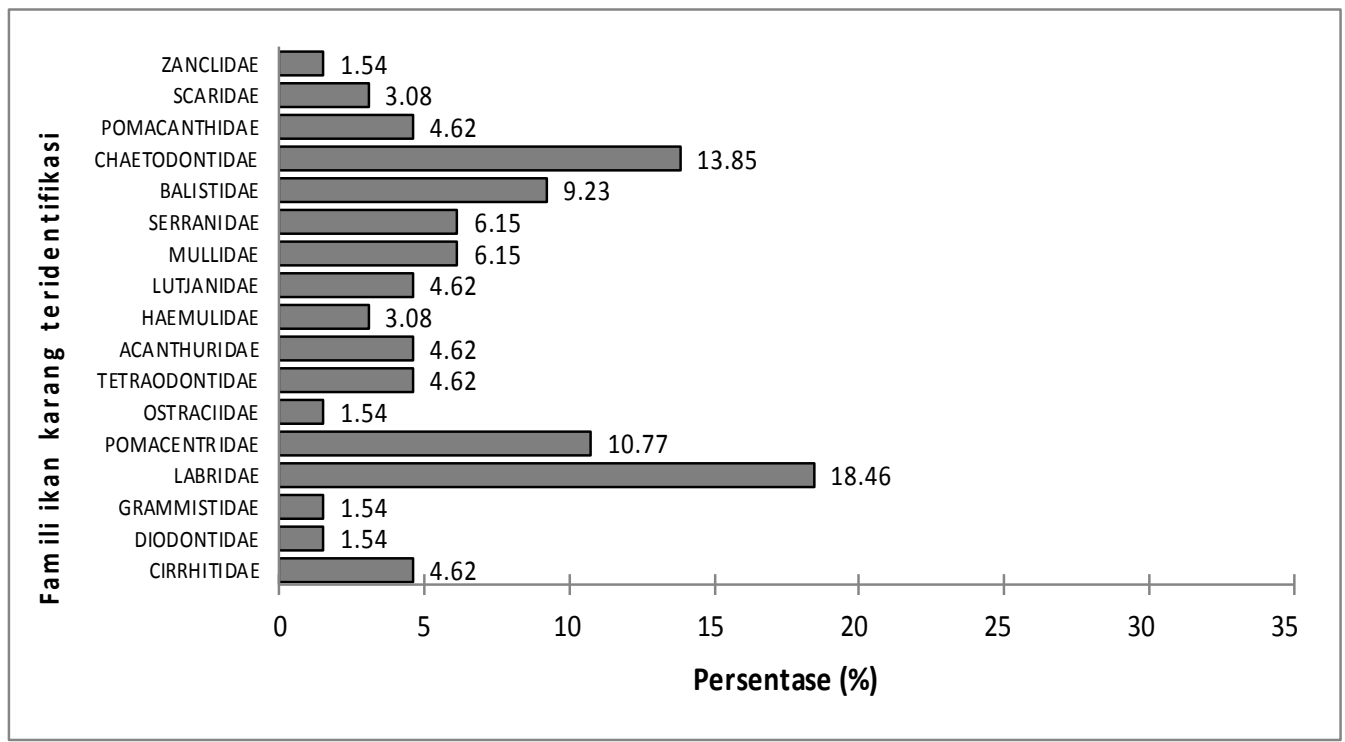

Gambar 3. Persentase spesies ikan karang yang teridentifikasi.

Picture 3. Percent of species of coral reef fish identified. 


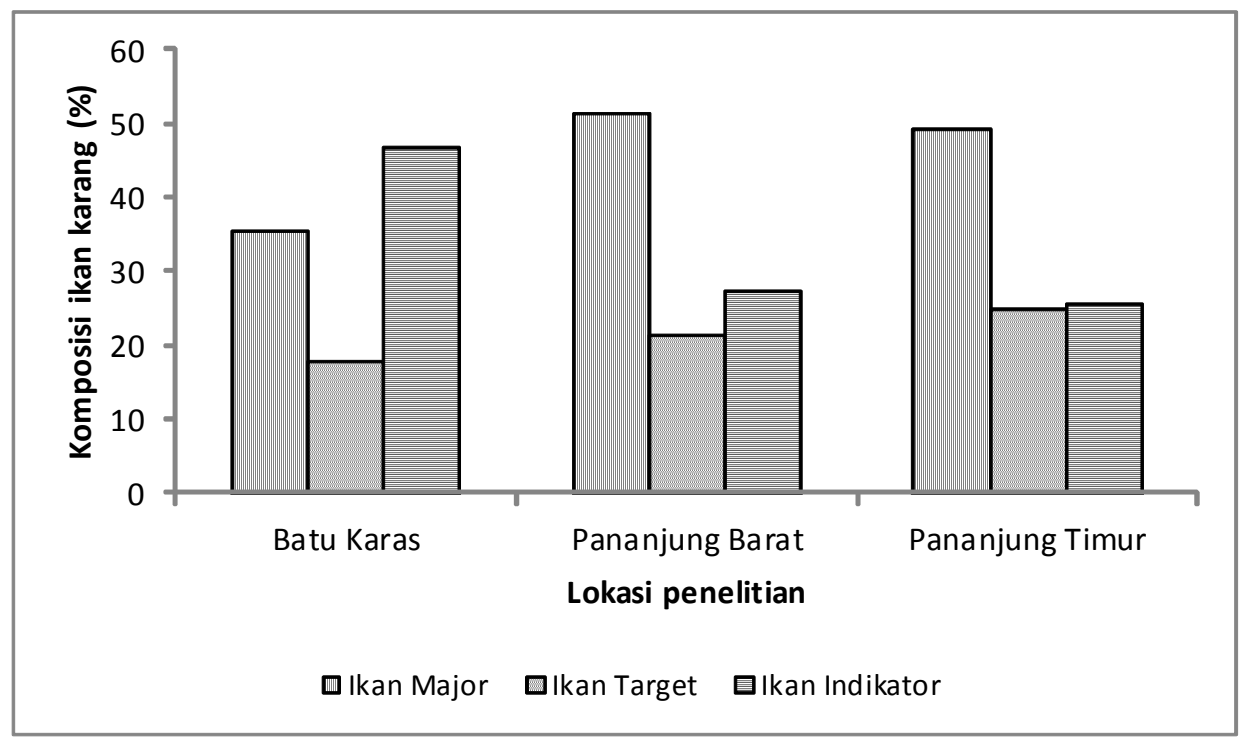

Gambar 4. Komposisi kelompok ikan karang berdasarkan jumlah individu.

Picture 4. Composition of group of coral reef fish by number of individuals.

Komposisi kelompok jenis ikan major yang merupakan komoditas utama komersil baik sebagai ikan konsumsi maupun ikan hias, teridentifikasi di lokasi penelitian berkisar antara 35,56-51,52\%. Kelompok ikan major ini berasosiasi dengan terumbu karang dan dipengaruhi oleh kolom perairan (Edrus et al., 2013). Kelompok ikan major yang teridentifikasi di lokasi penelitian terdiri dari 7 famili, yaitu Cirrhitidae, Diodontidae, Grammistidae, Labridae, Pomacentridae, Ostraciidae dan Tetraodontidae. Jenis yang paling banyak ditemukan di setiap lokasi penelitian adalah Plectroglyphidodon lacrymatus dari kelas Pomacentridae (Lampiran 1). Persentase jenis ikan target yang merupakan ikan konsumsi teridentifikasi di lokasi penelitian berkisar antara 17,7- $25 \%$. Pada kondisi yang normal di perairan karang tropis, kelompok ikan target pada umumnya adalah $30 \%$ dari jenis yang hidup di terumbu karang (Edrus et al., 2013). Kehadiran individu dan/ atau jenis ikan yang tergolong dalam kelompok ikan indikator di daerah penelitian berkisar antara 25,68-46,67\%. Kehadiran kelompok ikan indikator merupakan indikasi dari status kelayakan suatu perairan sebagai habitat hidup, seperti misalnya ikan kepe-kepe (Chaetodon spp) dari suku Chaetodontidae memberikan respon yang signifikan atas perubahan kondisi lingkungan (Edrus \& Syam, 1998)

Hasil perhitungan indeks ekologi, nilai indeks kekayaan jenis Margalef $(\mathrm{R})$ berkisar antara 5,09-8,68. Berdasarkan kriteria Jorgensen et al., 2005, nilai R>4 termasuk dalam kategori yang baik. Nilai indek keanekaragaman $(\mathrm{H})$ berkisar antara 2,57-3,36 yang masuk dalam kriteria sedang. Tidak terjadi dominasi dari suatu jenis ikan yang ditandai dengan indeks Dominasi (D) $<0,5$. Kemerataan jenis ikan di setiap lokasi penelitian sangat tinggi $(E>0,6)$ (Tabel 3). Hubungan antara kehadiran ikan dan kondisi tutupan terumbu karang disekitarnya disajikan pada Tabel 4 dan 5 .

Tabel 3. Indeks ekologi hasil analisis data sensus visual

Table 3. Index ecology data analysis visual census

\begin{tabular}{|c|c|c|c|c|}
\hline \multirow{2}{*}{$\begin{array}{c}\text { Lokasi Penelitian } \\
\text { (Research Location) }\end{array}$} & \multicolumn{4}{|c|}{ Indeks Biologi (Index Biology) } \\
\hline & $\mathbf{R}$ & D & $\mathbf{H}$ & $\mathbf{E}$ \\
\hline Batu Karas & 8,68 & 0,05 & 3,36 & 0,87 \\
\hline Pananjung Barat & 5,09 & 0,07 & 2,85 & 0,86 \\
\hline Pananjung Timur & 4,60 & 0,12 & 2,57 & $0, .81$ \\
\hline \multirow[t]{2}{*}{$\begin{array}{l}\text { Tabel } 4 . \\
\text { Table } 4 .\end{array}$} & $\begin{array}{l}\text { mpah } \\
\text { fish }\end{array}$ & $\begin{array}{l}\text { ngan tutupan alga } \\
\text { with percent cover }\end{array}$ & & \\
\hline & & Kelimpahan Ikan & & \% cover Algae \\
\hline Kelimpahan Ikan & & 1 & & \\
\hline$\%$ cover Algae & & 0,539224411 & & 1 \\
\hline
\end{tabular}


Tabel 5. Hubungan antara kelimpahan ikan dengan tutupan hard coral

Table 5. Correlation between fish abundance with percent cover of hard coral

\begin{tabular}{lcc}
\hline & Kelimpahan Ikan & \% cover Hard Coral \\
\hline Kelimpahan Ikan & 1 & 1 \\
$\%$ cover Hard Coral & 0,22563206 & \\
\hline
\end{tabular}

\section{Bahasan}

Hasil identifikasi kesehatan terumbu karang di perairan pantai pangandaran menunjukkan kondisi yang lebih buruk dibandingkan dengan beberapa perairan karang lainnya. Kondisi ini diduga selain disebabkan dampak terjadinya tsunami pada tahun 2016, juga masih adanya kegiatan penangkapan ikan dengan menggunakan peledak dan racun sianida. Mengacu PMO-COREMAP (2001), pada umumnya degradasi terumbu karang ditimbulkan oleh dua penyebab utama, yaitu kegiatan manusia (anthropogenic causes) dan aktivitas alam (natural causes). Kegiatan manusia yang menyebabkan kerusakan terumbu karang diantaranya adalah penambangan karang, penangkapan ikan dengan alat dan metode yang merusak, penangkapan ikan berlebih, pencemaran perairan, dan pembangunan di wilayah pesisir dan hulu. Sedangkan aktivitas alam yang menyebabkan kerusakan terumbu, diantaranya adalah pemanasan global (global warming), angin taufan (storm), gempa tektonik (earth), banjir (floods) dan tsunami serta fenomena alam lainnya, seperti El-Nino dan La-Nina. Hasil survai di Kepulauan Maluku membuktikan sekitar 65\% kerusakan terumbu karang disebabkan oleh pengeboman (Hopley \& Suharsono, 2000). Selanjutnya dinyatakan bahwa kerugian ekonomi dengan menggunakan sianida diperkiran sebesar US\$46 juta per tahun. Burke et al.(1996) dalam Sadhotomo et al.(2008), mengestimasi kerugian ekonomi di Indonesia dari penangkapan ikan dengan menggunakan peledak dalam 20 tahun yang akan datang mencapai US $\$ 570$ juta. Perubahan sedimen dan peningkatan turbiditas akibat tsunami di pantai barat Aceh telah merusak terumbu karang, dengan beberapa pemutihan terjadi sebagai akibat cahaya rendah dan debris pada badan air (Sadhotomo $e t$ al.,2008). Beberapa contoh kerusakan ekosistem terumbu karang yang disebabkan oleh aktivitas manusia di Maladewa, diantaranya adalah penggalian dasar laut untuk saluran navigasi, pengerukan dan reklamasi pantai di sekitar terumbu karang, menggali karang dan memindahkannya dekat pantai dengan tujuan untuk perlindungan pantai, penambangan karang massive, struktur pulau yang dimodifikasi, dan adanya tekanan di daerah padat penduduk di sekitar terumbu karang lakilaki (Kench \& Owen, 2015).

Hasil penelitian Edrus et al. (2010), bahwa kondisi terumbu karang di beberapa perairan sekitar timur Pulau Moyo, Teluk Saleh pada kondisi kesehatan terumbu karang sedang - baik, tutupan karang hidup pada kisaran 26,68 -
$57,71 \%$, dan hanya di Pulau Ketapang yang kondisinya buruk $(16,97 \%)$. Hasil identifikasi kesehatan terumbu karang di Kepualauan Seribu, dari 19 stasiun pengamatan, hanya 4 stasiun yang kondisinya buruk $(<25 \%)$, yaitu di perairan Goba Pulau Tikus, Pulau Genteng, Pulau Semak Daun, dan DPL Pulau Harapan (Wagiyo \& Hartati, 2013). Hartati et al.(2006) dalam Sadhotomo et al (2008), penutupan karang batu yang menunjukkan kesehatan terumbu karang di beberapa perairan Pulau Rakit dan Pulau Ganteng, Teluk Saleh NTB pada kisaran 34-52\% dan 20 $50 \%$. Selanjutnya hasil pengamatan tutupan karang batu di perairan Jemeluk, Bali pada tahun 2001 relatif tinggi yaitu rata-rata $88,33 \%$ setelah dilakukan rehabilitasi pada tahun 1991, dimana semula rata-rata hanya $21,52 \%$.

Karakteristik komunitas ikan dapat digunakan sebagai tolak ukur kesehatan relatif suatu ekosistem perairan (Thomas, 1999), karena lingkungan yang sehat akan mendukung untuk kehidupan biota didalamnya. Ikan karang pada umumnya bersifat territorial, namun karena ikan karang tersebut merupakan organisme yang selalu bergerak, keberadaannya dalan suatu habitat dipengaruhi oleh keadaan lingkungannya. Jika suatu lingkungan memiliki kondisi yang sesuai untuk kehidupannya, ikan karang akan mendiami lingkungan tersebut, namun jika lingkungannya berubah, ikan karang akan mencari lingkungan lain yang sesuai.

Berdasarkan hasil sensus visual kapadatan ikan karang di pantai Pangandaran relative rendah yaitu hanya berkisar $0,59-0,91 \mathrm{ind} / \mathrm{m}^{2}$, tertinggi di perairan Batu Karas dan yang terendah di Penanjung Timur. Menurut Djamali \& Darsono (2005) kapadatan ikan $1-5 \mathrm{ind} / \mathrm{m}^{2}$ adalah sangat jarang, $5-10 \mathrm{ind} / \mathrm{m}^{2}$ jarang, dan $10-20 \mathrm{ind} / \mathrm{m}^{2}$ cukup melimpah, 20-50 ind $/ \mathrm{m}^{2}$ melimpah, dan $>50 \mathrm{ind} / \mathrm{m}^{2}$ sangat melimpah. Kepadatan ikan karang hampir disemua terumbu karang di Indonesia adalah masuk dalam kriteria sangat jarang dan jarang. Kepadatan ikan karang di perairan Banggai Kepulauan yang kondisi karangnya masih relative lebih bagus, kepadatan ikan karang berkisar antara 2,7 $8,97 \mathrm{ind} / \mathrm{m}^{2}$ (Edrus \& Saputro, 2009). Hasil penelitian Wagiyo \& Hartati (3013), kepadatan ikan karang di daerah perlindungan laut (DPL) Kepulauan Seribu hanya berkisar $1,16-1,75 \mathrm{ind} / \mathrm{m}^{2}$, di perairan Nanggroe Aceh Darussalam yang juga pernah mengalami bencana tsunami, kepadatan ikan karang berkisar 2,2-13,2 ind $/ \mathrm{m}^{2}$.(Edrus et al, 2013), dan di perairan Pulau Rakiti dan Pulau Taikabo, Teluk Saleh, NTB kepadatan ikan karang berkisar 3,4-15,11 ind/ m2 (Hartati \& Edrus, 2005). 
Jenis yang paling banyak ditemukan adalah dari family Labridae (18.46\%). Jenis Labridae yang banyak ditemukan adalah Thalassoma lunare. Genus Thalassoma dikenal sebagai ikan karnivor yang memakan berbagai jenis hewan invertebrate seperti krustasea dan moluska (Choat \& Bellwood, 1991). Kondisi yang sama di temukan di Pulau Pari Kepulauan Seribu, family Labridae yang banyak muncul pada saat sensus visual, yaitu dari jenis Thalassoma lunare dan Thalassoma lutescens (Dhahyat et al. 2003). Jenis ikan dari genus Thalassoma banyak dijumpai di terumbu karang, karena sifatnya yang toleran pada habitat yang bervariasi (Chabanet \& Letourner, 1995).

Lokasi Batu Karas memiliki kelimpahan jenis ikan tertinggi dibandingkan dengan dua lokasi lainnya, terutama dari famili Balistidae dan Chaetodontidae. Banyaknya tipe karang foliose (13\%) di lokasi Batu Karas menjadi salah satu alasan banyak terdapatnya ikan dari famili Chaetodontidae yang menyukai celah-celah pada coral foliose (Arifin \& Yulianda, 2003). Sementara itu jenis ikan karang yang banyak ditemukan di lokasi Pananjung Barat dan Pananjung Timur adalah dari family Pomacentridae. Famili Pomacentridae merupakan jenis ikan karang yang paling banyak jenisnya dan sebagian besar berasosiasi dengan terumbu karang, memakan berbagai jenis invertebrate, alga dan zooplankton (Kuiter, 1992).

Ikan karang sering dikelompokkan untuk menggambarkan status dan pemanfaatannya. Pengelompokan seperti ini (kelompok status) sudah menjadi kesepakatan dan umum digunakan di Asia Pasifik. Kehadiran jensi-jenis ikan di terumbu karang dikelompokkan menjadi ikan indikator, ikan mayor atau ikan karang sejati, dan ikan target-predator yang merupakan ikan konsumsi. Komposisi yang normal dari masing-masing kelompok tersebut di perairan karang yang sehat adalah 10\%, 60\%, dan 30\% (Sadhotomo et al., 2008 ; Edrus \& Saputro, 2009). Selanjutnya komposisi tersebut berubah dari suatu perairan ke perairan lainnya sesuai dengan kondisi kesehatan perairan dan keragaman terumbu karang. Perubahan komposisi spesies ikan dan komposisi dari ketiga kelompok ikan, terutama ikan indikator mengindikasikan bahwa telah terjadi perubahan kondisi karang dan badan air di suatu perairan. Perubahan dapat bersifat positif dan negative, namun perubahan kearah negative lebih sering terjadi, sehingga mengganggu komunitas ikan dan mengubah komposisi spesies yang ada. Beberapa factor yang mempengaruhi kondisi ikan karang dan karang batu di Indonesia, diantaranya adalah penambangan karang, pencemaran dan sedimentasi, penangkapan ikan dengan jarring, bom dan racun, serta pemutihan karang akibat Acanthaster planci dan El-Nino.

Perubahan kelompok ikan juga terjadi di perairan pantai Pangandaran. Komposisi kelompok ikan mayor di pantai pangandaran pada kisaran 36-53\%, ikan target 18$25 \%$, dan ikan indikator $25-46 \%$. Tingginya kelompok ikan indikator ditunjukkan dari kehadiran beberapa jenis ikan dari kelompok Chaetodontidae. Kebanyakan para ahli menggunakan famili chaetodontidae sebagai ikan indikator, yaitu terdiri dari 120 spesies dan 10 marga hidup di perairan tropik dan sub tropik, dengan warna yang beranekaragam. Kelompok ikan mayor memiliki ketergantungan atau afinitas yang sangat kuat pada terumbu karang. Pada kasus perubahan karang (habitat) atau perubahan dalam bentuk kehidupan karang (reef lifeform), komposisi spesies dari kelompok ikan mayor akan berubah. Ada spesies yang bertahan karena memiliki adaptasi fungsi dan variasi makanan kegemaran dan ada pula spesies yang hilang karena lingkungan yang tidak nyaman dan tidak sesuai dengan fungsi relungnya serta kebiasaan makananya. Pada kondisi kerusakan karang dan pencemaran badan air, komposisi ikan mayor berubah secara signifikan dan digantikan oleh kelompok ikan target (Sadhotomo et al, 2008). Ikan target atau predator pada umumnya adalah ikan konsumsi, hidup di terumbu karang dan perairan sekitarnya. Ikan target merupakan sasaran tangkapan nelayan karena pada umumnya memiliki tubuh yang besar. Diantara dari jenis-jenis dari ikan target adalah kerapu, bibir tebal, biji nangka, kakap merah atau bambangan, lencam, pasir-pasir, ekor kuning, napoleon, baronang, dan kuwe. Ikan kerapu, kakap merah atau bambangan dan jenis ikan karang lainnya merupakan target utama tangkapan nelayan di pantai Pangandaran sebagai daerah wisata, produksinya pada 3 tahun terakhir (2012-2014) mencapai kurang lebih 20 ton.

Hasil perhitungan indeks keanekaragaman $(\mathrm{H})$ ikan karang selama penelitian berkisar antara 2,57 - 3,36. Berdasarkan nilai indeks keanekaragaman tersebut, keanekaragaman jenis ikan karang di lokasi penelitian termasuk dalam kategori sedang. Nilai indeks keanekaragaman berhubungan dengan jumlah kehadiran jenis dan pola distribusi jumlah masing masing populasi dalam komunitas (Edrus et al., 2013). Di setiap lokasi penelitian tidak terjadi dominasi dari salah satu jenis ikan yang ditandai dengan indeks dominasi $<0,5$ dan nilai indeks kemerataan yang termasuk dalam kategori tinggi $(>0,6)$ (Odum, 1971). Indeks kekayaan jenis (R) merupakan petunjuk langsung dari tingginya keanekaragaman mahluk hidup di perairan pantai Pangandaran.

Berdasarkan hasil analisis korelasi antara kehadiran ikan dan kondisi terumbu karang disekitarnya, hubungan yang lebih signifikan diperlihatkan antara kehadiran ikan dengan persentase tutupan alga $(0,54)$. Sedangkan hubungan antara kehadiran ikan dan persentasi tutupan hard coral memiliki nilai korelasinya relatif kecil $(0,22)$. Analisis ini menunjukkan adanya dugaan telah terjadi recovery terumbu karang yang telah mengalami kerusakan di perairan pantai pangandaran yang ditunjukkan dengan 
kehadiran biota penempel, seperti alga dan kehadiran ikan/ biota indikator yang relative melimpah.

\section{KESIMPULAN}

Kondisi terumbu karang di perairan pantai Pangandaran, Jawa Barat dalam kondisi buruk. Diduga dampak bencana alam tsunami yang terjadi pada tahun 2006 dan aktifitas penangkapan ikan dengan menggunakan bom dan racun. Teridentifikasi 66 jenis ikan karang dengan kepadatan pada kriteria sangat jarang, yaitu kurang dari $1 \mathrm{ind} / \mathrm{m}^{2}$. Indeks ekologis komunitas ikan karang yang secara temporal dapat menggambarkan peningkatan atau sebaliknya penurunan mutu lingkungan perairan karang menunjukkan kategori baik untuk indeks kekayaan, sedang untuk indeks keanekaragaman jenis, tidak terjadi dominasi jenis ikan karang tertentu dan kemerataan populasi di lokasi penelitian pada kategori tinggi. Hubungan antara kehadiran ikan dengan tutupan alga lebih signifikan dari pada hubungan antara ikan dengan tutupan karang batu, diduga telah terjadi recovery terumbu karang yang telah mengalami kerusakan di perairan pantai pangandaran.

\section{PERSANTUNAN}

Data yang dipergunakan dalam makalah ini adalah sebagian dari hasil kegiatan penelitian Ecological Assessment untuk Restoking Benih Lobster di Kawasan Konservasi Perairan Indonesia, Balai Penelitian Pemulihan dan Konservasi Sumber Daya Ikan Jatiluhur pada tahun 2015.

\section{DAFTAR PUSTAKA}

Anonim. (2013). https : // tonimpa.wordpress.com. /2013/ 12/18/ Makalah Terumbu Karang (Diunduh 2 Mei 2016 pukul 12.33 WIB).

Allen, G. R. (1997). Marine Fishes of Tropical Australia and South East Asia. A Field Guide for Angler and Diver. Western Australia Museum.

Badrudin, Suharti, S.R., Yahmantoro \& Suprihanto, I. (2003). Indeks keanekaragaman hayati ikan kepe-kepe (Chaetodontidae) di perairan Wakatobi, Sulawesi Tenggara. J.Lit.Perik.Ind. 9(7), 67-73.

Choat, J. H \& Bellwood, D.R. (1991). The Ecology of fishes on coral reefs. Reef Fishes: Their History and Evolution (p.39-47). Sale PF. Eds. Departement of Zoology University of New Hamshire Durham.

Chou, L. M. (1998). Status of Southeast Asian Coral Reefs. In Status of Coral Reefs of the World: 1998. C. Wilkinson (Ed). Sida-Australian Institute of Marine
Science. ICLARM Publ. Quensland. Australia.

Dhahiyat, Y., Sinuhaji, D \& Hamdani, H. (2003). Struktur kominitas ikan karang di daerah transplantasi karang Pulau Pari, Kepulauan Seribu. Jurnal Iktiologi Indonesia. 3(2), 87-94.

Djamali, A., \& Darsono, P. (2005). Petunjuk teknis lapangan untuk penelitian ikan karang di ekosistem terumbu karang. Materi kursus. Pusat Dokumentasi dan Informasi Ilmiah. Lembaga Ilmu Pengetahuan Indonesia. Jakarta.

Edrus, I.N., \& Saputro, G.B. (2009). Struktu Komunitas Ikan Karang di Perairan Banggai Kepulauan, Sulawesi Tengah. J.Lit.Perik.Ind. 15(3),

Edrus, I.N., Aris, S \& Setyawan, I.E. (2010). Kondisi Kesehatan Terumbu Karang Teluk Saleh, Sumbawa. Tinjauan Aspek Substrat Dasar Terumbu dan Keanekaragaman Ikan Karang. Edrus, I.N \& G.B. Saputro. (2009). Struktu Komunitas Ikan Karang di Perairan Banggai Kepulauan, Sulawesi Tengah. J.Lit.Perik.Ind. 16 (2), 147-161.

Edrus, I. N., Wijaya, S. W \& Setyawan, I.E. (2013). Struktur komunitas ikan karang di perairan Pulau Raya, Pulau Rusa, Pulau Rondo. Edrus, I.N \& G.B. Saputro. (2009). Struktu Komunitas Ikan Karang di Perairan Banggai Kepulauan, Sulawesi Tengah. J.Lit.Perik.Ind. 19 (4): 175-186.

English, S., William, C \& Baker, V. (1994). Suney Manual of Tropical Marine Resources (p. 112). Asean - Aushalian Marine Project. Australia.

Hartati, S.T \& Edrus, I.N. (2005). Komunitas Ikan Karang di Perairan Pantai Pulau Rakiti dan Pulau Taikabo, Teluk Saleh, NTB. J.Lit.Perik.Ind. Edisi Sumber Daya dan Penangkapan. 11(2).

Hopley, D \& Suharsono. (2000). The Status of Coral Reefa in Eastern Indonesia (p. 38). Townssville, Australia: Global Coral Reef Monitoring Network.

Kench, P.S \& Owen, S.D. (2015). Coral Reef Systems and the Complexity of Hazards. Coastal and Marine Hazards, Risk \& Disasters.

Kuiter, C. J. (1992). Tropical Reef Fish ofWestern Paci/ic. Indonesia and Adjacent Waters (p.314). PT. Gramedia Pustaka Utama. Jakarta.

Leiske, E \& Myers, R. (1995). Coral reef fishes of Indo Pasific and Caribean (p. 400). Harper collin Publish. 
Mason, C.F. (1981). Biology of fresh water pollution. Longman scientific and technical. Longman Singapore Publisher Ptc. Ltd. Singapore.

Odum, E. P. (1971). Fundamental of ecology (p.574). W.B. Sounders, Philadelphia.

Pielou, E. C. (1975). Ecological diversity (p.165). John Wiley \& Sons. New York.

PMO-COREMAP. (2001). Naskah Kebijakan Nasional Pengelolaan Terumbu karang di Indonesia.

Radiarta, I.N \& Jonly Emor. (2003). Sumberdaya ikan pada ekosistem terumbu karang di Kepulauan Sangihe Talaud, Sulawesi Utara. J.Lit.Perik.Ind. 9(3), 73-82.
Sadhotomo, B., Badrudun, M., Nugroho, D., Widjopriono., Rahardjo, P., Hartati, S.T., Nuraeni, S., Mahiswara., Edrus, I.N., Panggabean, A.S., Priatna, A \& Zainy, R. (2008). Perikanan Terumbu Karang. Biodynex. Balai Riset Perikanan laut. Badan Riset Kelautan dan Perikanan.

Sale, P. F. (1991). The Ecology of fishes on coral reef. Oceanography. Marine. Biology. 18, 367-421.

Suharsono. (1996). Jenis-jenis karang yang umum dijumpai di perairan Indonesia. Pusat Penelitian dan Pengembangan Oseanografi, LIPI. Jakarta.

Wagiyo, K. \& Hartati, S.T. (2013). Sediaan dan Kondisi Habitat Ikan Karang Konsumsi (Serranidae, Caesionidae, Scaridae) di Perairan kepulauan Seribu. Status Pemanfaatan Sumber Daya Ikan di Perairan Laut Jawa. Balai Penelitian Perikanan laut. 
Lampiran 1. Hasil identifikasi ikan karang di Batu Karas, Penanjung Barat, dan Penanjung Timur, Pangandaran Jawa Barat Bulan Mei 2015.

Appendix 1. Result of reef fishes identification in Batu Karas, Penanjung Barat and Penanjung Timur, Pangandaran-West Java on May 2015.

\begin{tabular}{|c|c|c|c|c|}
\hline No & Jenis Ikan & Batu Karas & Penanjung Barat & Penanjung Timur \\
\hline 1 & Acanthurus auranticapus & 3 & & 4 \\
\hline 2 & Acanthurus lineatus & & 2 & 14 \\
\hline 3 & Amphiprion ocellaris & & & 3 \\
\hline 4 & Anampses sp. & 1 & & \\
\hline 5 & Arothron stellatus & 1 & & \\
\hline 6 & Balistoides viridescens & 2 & & \\
\hline 7 & Canthigaster solandri & & 2 & \\
\hline 8 & Canthigaster valentini & & 2 & \\
\hline 9 & Centropyge bicolor & 1 & & \\
\hline 10 & Centropyge eibli & 3 & 21 & 4 \\
\hline 11 & Centropyge tibicen & 2 & & \\
\hline 12 & Cephalopholis argus & & 1 & \\
\hline 13 & Cephalopholis boenack & & 1 & \\
\hline 14 & Cephalopholis fasciatus & & 1 & \\
\hline 15 & Chaetodon citrinellus & 1 & 1 & \\
\hline 16 & Chaetodon decusatus & 2 & & 2 \\
\hline 17 & Chaetodon kleinii & 4 & 14 & 6 \\
\hline 18 & Chaetodon lunula & 2 & & \\
\hline 19 & Chaetodon trifasciatus & 2 & & 2 \\
\hline 20 & Chaetodon vagabundus & 4 & 2 & 2 \\
\hline 21 & Cheilinus bimaculatus & 1 & & \\
\hline 22 & Chlorurus sordidus & 6 & & 6 \\
\hline 23 & Chromis margaritifer & & & 1 \\
\hline 24 & Chrysiptera cyanea & 6 & 8 & \\
\hline 25 & Cirrhitichthys falco & 1 & & \\
\hline 26 & Cirrhitichthys oxycephalus & 2 & 1 & \\
\hline 27 & Coris sp. & 2 & & \\
\hline 28 & Ctenochaetus striatus & & 14 & 17 \\
\hline 29 & Dascyllus reticulatus & & 17 & \\
\hline 30 & Dascyllus trimaculatus & 14 & 6 & 8 \\
\hline 31 & Diodon hystrix & 1 & & \\
\hline 32 & Diploprion bifasciatum & & 3 & \\
\hline 33 & Epinephelus quoyanus & 1 & & \\
\hline 34 & Halichoeres dussumieri & 4 & & \\
\hline 35 & Halichoeres hortulanus & & 3 & \\
\hline 36 & Halichoeres melanurus & & & 1 \\
\hline 37 & Halichoeres trimaculatus & 1 & & 2 \\
\hline 38 & Heniochus acuminatus & 18 & & \\
\hline 39 & Heniochus monoceros & 6 & & \\
\hline 40 & Heniochus varius & 2 & & \\
\hline
\end{tabular}


Lanjutan Lampiran 1..........

Continue Appendix 1........

\begin{tabular}{|l|l|c|c|c|}
\hline 41 & Labroides bicolor & 1 & 12 & 1 \\
42 & Labroides dimidiatus & 3 & & \\
43 & Lutjanus fulvus & & & \\
44 & Lutjanus kasmira & 4 & 1 & \\
45 & Lutjanus vitta & 2 & & \\
46 & Melichthys niger & 9 & & \\
47 & Mulloidichthys flavilineatus & 34 & & \\
48 & Naso annulatus & 7 & & \\
49 & Naso thynnoides & 6 & & \\
50 & Ostracion cubicus & 1 & 4 & \\
52 & Paracirrhites forsteri & 2 & & \\
53 & Parupeneus barberinus & 13 & & \\
54 & Parupeneus indicus & 3 & & \\
55 & Parupeneus macronema & 1 & & \\
56 & Plectorhinchus lineatus & 2 & & \\
57 & Plectorhinchus vittatus & 19 & & \\
58 & plectroglyphidodon lacrymatus & & & \\
59 & Pomacentrus chrysurus & & & \\
60 & Scarus dimidiatus & & \\
\hline
\end{tabular}


Lanjutan Lampiran 1..........

Continue Appendix 1

\begin{tabular}{|c|c|c|c|c|}
\hline 61 & Stethojulis trilineata & 5 & \multirow{2}{*}{$\begin{array}{l}3 \\
2\end{array}$} & \multirow[b]{2}{*}{1} \\
\hline 62 & Sufflamen bursa & 4 & & \\
\hline 63 & Suflamen chrysopterus & 2 & & \\
\hline 64 & Thallasoma jansenii & 3 & 3 & \\
\hline 65 & Thallasoma lunare & 8 & \multirow[t]{2}{*}{9} & 2 \\
\hline 66 & Zanclus cornotus & 3 & & 9 \\
\hline & TOTAL INDIVIDU & 225 & 165 & 148 \\
\hline & TOTAL JENIS & 48 & 27 & 24 \\
\hline & KEPADATAN & 0,91 ind $/ \mathrm{m}^{2}$ & 0,67 ind $/ \mathrm{m}^{2}$ & 0,59 ind $/ \mathrm{m}^{2}$ \\
\hline
\end{tabular}

